\title{
Heavy Metals accumulation in fish species of Savitri River in Raigad district of Maharashtra
}

\author{
K.Yardi, R. Jayasuriya* and K. Gurav \\ Bharati Vidyapeeth Institute of Environment, Education \& Research (BVIEER), Katraj, Pune, India \\ kranti@bvieer.edu.in, jayasuriya.rohan.15@gmail.com*, kgearth@gmail.com
}

\begin{abstract}
A study was carried out to investigate the contamination of heavy metals in muscle and intestine tissue in 7 fish species and 1 prawn species, caught at upstream and downstream points along the Savitri River in the Raigad district of Maharashtra. The river course has a discharge point in which the Common Effluent Treatment Plant (CETP) discharges its treated effluent. Water analysis was carried out from 10 different locations in the upstream and downstream of the river from the discharge point. The common fish species available in the river course were collected and toxicity tests were carried out for the muscle and intestine samples for 3 metals: lead $(\mathrm{Pb})$, cadmium $(\mathrm{Cd})$ and mercury $(\mathrm{Hg})$ by Atomic Absorption Spectroscopy (AAS). The results showed that lower metal values were recorded in the water than fish organs. The concentrations of metals $\left(\mathrm{mg} \mathrm{lit}^{-1}\right)$ in water were below the levels recommended by the Maharashtra Pollution Control Board for drinking, except for $\mathrm{Pb}(0.31 \pm 0.02)$. The highest concentration $\left(\mathrm{mg} \mathrm{lit}^{-1}\right)$ of all heavy metals was recorded upstream, in the intestine of Etroplus suratensis (3.42 $\pm 0.07 \mathrm{for} \mathrm{Pb}$ ) while the lowest was recorded downstream, in the muscle of Cynoglossus macrolepidotus $(0.07 \pm 0.01$ for $\mathrm{Hg})$. There were significant differences $(\mathrm{P}<0.05)$ between mean concentrations in muscle and intestine as compared to water samples at both upstream and downstream sampling points. However, no significant differences $(\mathrm{P}>0.05)$ were recorded in mean concentrations between muscle and intestine in species, except for $\mathrm{Cd}$ and $\mathrm{Hg}$ levels in Liza tade, caught upstream and Cd level in Machrobrachium malcolmsonni, caught downstream $(\mathrm{P}<0.05)$. Overall results indicated that fish organs were slightly contaminated by heavy metals, mainly by $\mathrm{Pb}$, but did not exceed the levels recommended by the Indian Food Safety \& Standards regulation (FSSAI), 2011.
\end{abstract}

Keywords: Heavy metal toxicity, CETP, fish, muscle, intestine

\section{Introduction}

The Raigad District is a part of the west coast of the Arabian Sea, located in the state of Maharashtra. This district has various prominent industrial areas which includes MIDC areas \& Co-operative Industrial Estates. There are three major industrial Estates developed by MIDC, of which one is the MIDC Mahad, located in catchments of the Savitri River basin. Mainly chemical industries have been established in these industrial estates. The industrialization in this District has warranted protection of environment in general. The effluent collected from 127 industries is collected and treated at a CETP (Common Effluent Treatment plant) developed by MIDC. The capacity of the CETP, in Mahad is 7.5 MLD. The CETP has pre-primary, primary, secondary and tertiary treatment facilities. The effluent coming out from the CETP is discharged to the Bankot Creek of Savitri River which is at a distance of about $26 \mathrm{~km}$ from the CETP.

The water from this river is used by the industries and people from nearby villages for their daily needs. Hence the high load of heavy metals entering the river body from various sources including the CETP at Mahad is of major concern. Fish being the staple diet of the people, may accumulate large amounts of certain metals above the standard levels (Deb and Santra, 1997). Studies carried out on fish have shown that heavy metals like $\mathrm{Pb}, \mathrm{Cd}$, and $\mathrm{Hg}$ may have toxic effects, altering physiological activities in tissues of fish (Larsson et al., 1985; Nemesok and Huphes, 1988; Abel et al., 1986). Hence fish are used as indicators of heavy metal contamination in the ecosystem (Blasco et al., 1998).

The main objective of this study was to investigate the levels of heavy metal in the muscle and intestine tissue of some common fish species found in the Mahad region and compare this with the level found in the river water. This is done to assess the quality of river water as per MPCB (Maharashtra Pollution Control Board) norms as well as to assess the health risks to people consuming these fish. This information would be a useful tool for further improvisations in the treatment of effluent by the CETP and thus effective management and control of the surrounding natural area. 


\section{Materials and methods}

\subsection{Study Area}

The area of study includes upstream and downstream sampling sites selected along the Savitri River, located on both sides of discharge point, as described in Fig 1 . The study area is bounded between $18^{\circ} 32^{\prime} \mathrm{N}$ and $73^{\circ} 45^{\prime} \mathrm{E}$. Table 1 shows sampling points and their respective distances from the discharge point.

Fig.1. Sampling sites along Savitri River

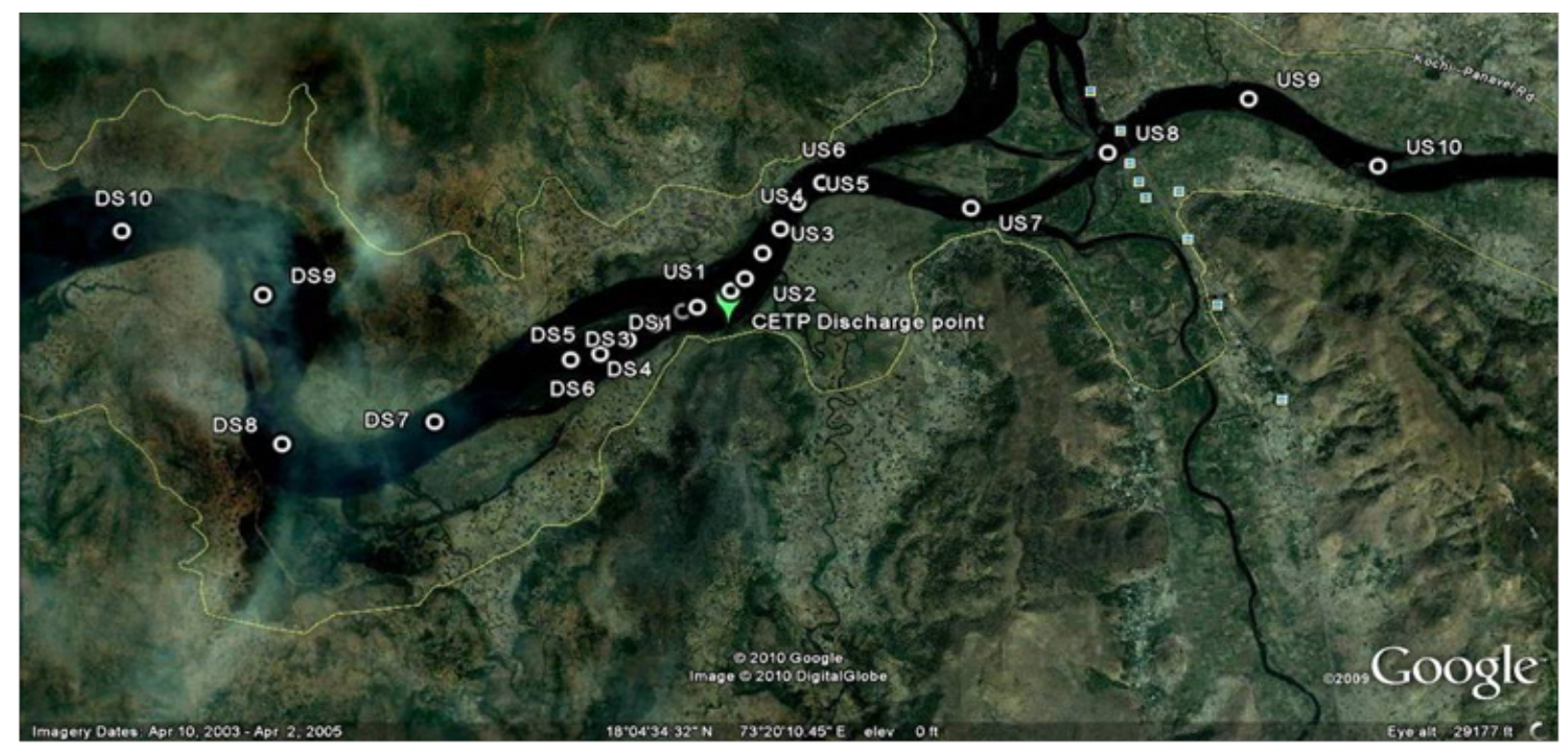

Fig.2. Mean distribution of $\mathrm{Pb}$ in fish

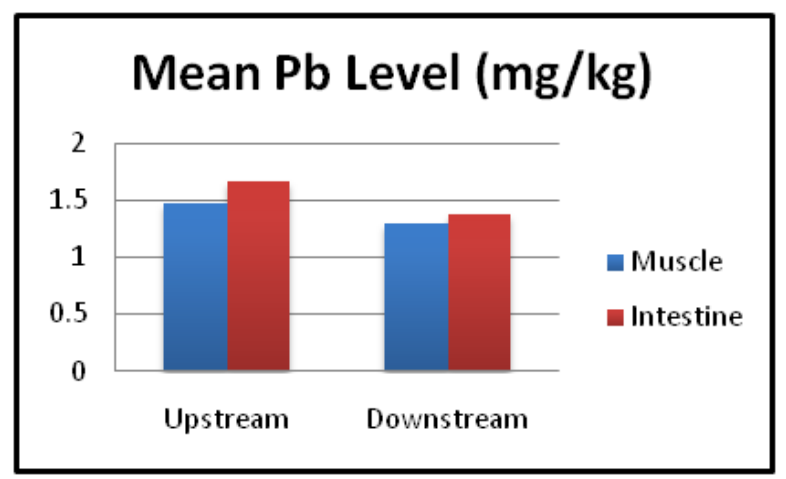

Fig.4. Mean distribution of $\mathrm{Hg}$ in fish

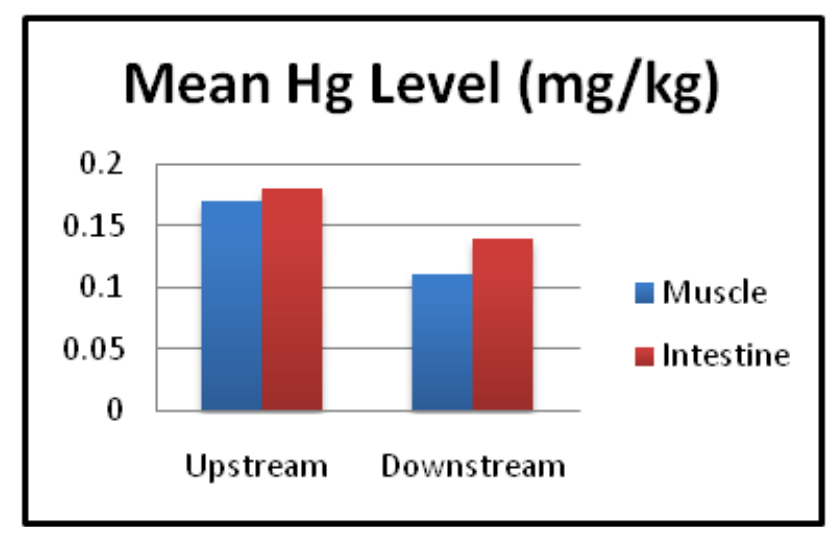

Fig.3. Mean distribution of $\mathrm{Cd}$ in fish

\section{Mean Cd Level (mg/kg)}

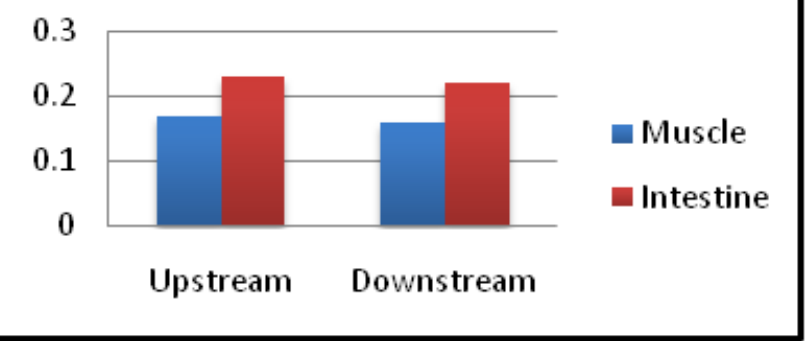




\subsection{Sample collection and preparation}

Seven fish species along with one prawn species (Table 2) were collected from all sampling sites for this study, by means of various fishing gear and nets. Atleast three to five samples from each fish species were obtained. After capture, fish samples were immediately frozen at $-20^{\circ} \mathrm{C}$. Water samples were collected randomly from both downstream and upstream points, sealed, stored in plastic containers and transported to laboratory in iced packs along with fish samples. Fish samples were thawed at room temperature and their organs were obtained by dissection using stainless steel dissecting instruments. After dissection, all samples (muscle and intestine) were labeled according to their species.

Table 1. Sampling points and their respective distances from the discharge point

\begin{tabular}{||c||c|c||}
\hline S. No. & $\begin{array}{l}\text { Upstream and down- } \\
\text { stream Sampling points }\end{array}$ & $\begin{array}{l}\text { Distance from } \\
\text { discharge point }\end{array}$ \\
\hline \hline 1 & US1 \& DS1 & 100 meter \\
\hline 2 & US2 \& DS2 & 200 meter \\
\hline 3 & US3 \& DS3 & 400 meter \\
\hline 4 & US4 \& DS4 & 600 meter \\
\hline 5 & US5 \& DS5 & 800 meter \\
\hline 6 & US6 \& DS6 & 1000 meter \\
\hline 7 & US7 \& DS7 & $2 \mathrm{~km}$. \\
\hline 8 & US8 \& DS8 & $3 \mathrm{~km}$. \\
\hline 9 & US9\& DS9 & $4 \mathrm{~km}$. \\
\hline 10 & US10\& DS10 & $5 \mathrm{~km}$. \\
\hline
\end{tabular}

Table 2. List of species and their physical characteristics

\begin{tabular}{|l|l|l|l|l|l|}
\hline S. No. & Species & Habitat & Length $(\mathrm{cm})$ & Width $(\mathrm{cm})$ & Weight $(\mathrm{gm})$ \\
\hline \hline 1 & Etroplus suratensis & US & $5.6-5.9$ & $2.4-2.6$ & $3.4-5.4$ \\
\hline 2 & Leiognathus equulus & US & $9-10.8$ & $3-3.6$ & $12-18$ \\
\hline 3 & Tetraodon nigroviridis & US & $5.5-12$ & $1.5-4.3$ & $16.7-54.6$ \\
\hline 4 & Liza tade & US & $11.6-13.3$ & $2.2-2.6$ & $16.5-29.2$ \\
\hline 5 & Glossogobius giuris & DS & $10-11.2$ & $1.4-1.5$ & $9.3-12.6$ \\
\hline 6 & Cynoglossus macrolepidotus & DS & $11.4-13.5$ & $2.8-3.5$ & $10.8-19$ \\
\hline 7 & $\begin{array}{l}\text { Machrobrachium } \\
\text { malcolmsonni }\end{array}$ & DS & $5-7.2$ & $1-1.5$ & $2-4.1$ \\
\hline 8 & Ambassis commersoni & DS & $8.9-12$ & $2.5-3.8$ & $7.3-21.5$ \\
\hline
\end{tabular}

Fish organs were thawed and rinsed in distilled water. Samples were separately dried in an oven at $120^{\circ} \mathrm{C}$ for 24 hours. $1 \mathrm{~g}$ of ground tissue was accurately weighed into $100 \mathrm{ml}$ flasks. $5 \mathrm{ml}$ perchloric acid and $15 \mathrm{ml}$ nitric acid were added and digestion was performed on a hot plate at $150^{\circ} \mathrm{C}$ under a hood till solutions were clear of fumes of perchloric acid (Van Loon, 1980). Contents of the flask were made up to $50 \mathrm{ml}$ with distilled water and then filtered using 0.5 micron filter membrane and stored for a fortnight, before determining metal concentration. All samples were analyzed (APHA, 2005) in triplicate for 3 heavy metals in a Hatch Model DR 300 Spectra Atomic Absorption Spectrophotometer (AAS). Values obtained were expressed in $\mathrm{mg} / \mathrm{lit}$. Digested fish samples were analyzed for heavy metal concentration as per water and values obtained were expressed in $\mathrm{mg} / \mathrm{kg}$ dry weight. The actual concentration of each metal was calculated using the formula:

Actual concentration of metal in samples = AAS reading of digest $x$ Dilution factor (Olaifa et al., 2004)

Dilution Factor $=$ Volume of digest used $/$ Weight of sample digested 
Vol:5 | Issue:10 | October 2012 | ISSN:0974-6846 Indian Journal of Science and Technology

Physico-chemical parameters of water determined were dissolved oxygen (DO), chemical oxygen demand (COD) and pH as per APHA, 2005.

\subsection{Data Statistics}

Tests of significance were performed using SPSS 11.5 software. A P-value of 0.05 was considered statistically significant. One way ANOVA (Ozdmar, 1999) compared metal concentrations in intestine and muscle of each species at upstream and downstream points, compared metal concentrations between water samples and tissue samples as well as physico-chemical parameters at upstream and downstream locations. Means of significance were separated using Duncan's multiple range test. $(\mathrm{P}<0.05)$

\section{Results}

Results of the physico-chemical parameters of water samples, at upstream and downstream locations are presented in Table 3.

Table 3. physico-chemical parameters of water samples, at upstream and downstream locations

\begin{tabular}{|l|l|l|}
\hline Parameters & US & DS \\
\hline \hline $\mathrm{pH}$ & $7.42 \pm 0.18$ & $7.65 \pm 0.24$ \\
\hline $\mathrm{DO}$ (mg lit- 1$)$ & $6.35 \pm 0.85$ & $6.57 \pm 0.84$ \\
\hline $\mathrm{COD}$ (mg lit- 1$)$ & $97.3 \pm 16.3$ & $124.0 \pm 20.0$ \\
\hline
\end{tabular}

Each value is the mean of 10 replicate analyses of samples taken at the 10 locations upstream and downstream, as indicated in table 1. Results show that the water downstream has comparatively higher dissolved oxygen, is more acidic and has higher chemical oxygen demand when compared to water samples at upstream locations. Significant differences $(\mathrm{P}<0.05)$ were recorded between mean dissolved oxygen concentrations and $\mathrm{pH}$ at the two locations. No significant differences $(\mathrm{P}>0.05)$ were recorded between $\mathrm{COD}$ at both locations.

The metals analyzed include Lead, Cadmium and Mercury. The heavy metal content in the muscle and intestine tissue were compared with metal levels in the water at both upstream and downstream locations. The results are presented in Tables 4 and 5 .

Table 4. Comparison of Heavy metal content in muscle, intestine ( $m g \mathrm{~kg}-1)$ and water (mg lit-1) at upstream points

\begin{tabular}{|l|l||l|l|l|}
\hline \hline Sr. No. & Fish Organ & $\mathrm{Pb}$ & $\mathrm{Cd}$ & $\mathrm{Hg}$ \\
\hline \hline \multirow{2}{*}{1} & Intestine & $3.42 \pm 0.07 \mathrm{a}$ & $2.96 \pm 0.09 \mathrm{a}^{*}$ & $0.26 \pm 0.01 \mathrm{a}$ \\
\cline { 2 - 5 } & Muscle & $0.29 \pm 0.02 \mathrm{a}$ & $0.25 \pm 0.01 \mathrm{a}^{*}$ & $0.25 \pm 0.01 \mathrm{a}^{*}$ \\
\hline 2 & Intestine & $1.66 \pm 0.50 \mathrm{bc}$ & $0.24 \pm 0.01 \mathrm{~b}$ & $0.18 \pm 0.01 \mathrm{~b}$ \\
\hline & Muscle & $1.50 \pm 0.02 \mathrm{~b}^{*}$ & $0.21 \pm 0.01 \mathrm{~b}^{*}$ & $0.16 \pm 0.03 \mathrm{~b}^{*}$ \\
\hline 3 & Intestine & $1.15 \pm 0.03 \mathrm{~cd}$ & $0.14 \pm 0.04 \mathrm{c}$ & $0.13 \pm 0.02 \mathrm{c}$ \\
\hline & Muscle & $0.78 \pm 0.03 \mathrm{c}^{*} \mathrm{~d}^{*}$ & $0.13 \pm 0.01 \mathrm{c}^{*}$ & $0.11 \pm 0.02 \mathrm{c}^{*}$ \\
\hline 4 & Intestine & $0.46 \pm 0.19 \mathrm{~d}$ & $0.24 \pm 0.03 \mathrm{bd}$ & $0.14 \pm 0.01 \mathrm{c}$ \\
\hline & Muscle & $0.67 \pm 0.29 \mathrm{~d}^{*}$ & $0.1 \pm 0.01 \mathrm{c}^{*}$ & $0.18 \pm 0.02 \mathrm{~b}$ \\
\hline & Water & $0.30 \pm 0.02 \mathrm{c}^{*} \mathrm{~d}$ & $0.03 \pm 0.02 \mathrm{e}$ & $0.001 \pm 0.001 \mathrm{e}$ \\
\hline Criteria & FSSAl & $2.5-5$ & 1.5 & 0.5 \\
\hline $\begin{array}{l}\text { Data are presented as means } \pm \text { SE of three determinations. Means followed by } \\
\text { the same letter within columns are not significantly different at 5\% level }\end{array}$ \\
\hline
\end{tabular}

In the muscle, intestine and water significant differences $(\mathrm{P}<0.05)$ were recorded in the concentration of all three heavy metals at both upstream and downstream locations. However, no significant differences $(\mathrm{P}>0.05)$ were recorded in metal concentrations between muscle and intestine, except for $\mathrm{Cd}$ and $\mathrm{Hg}$ levels in Liza tade, caught upstream and Cd level in Machrobrachium malcolmsonni, caught downstream.

The content of lead in muscle was lower than that in intestine, except for Liza tade found at upstream location and Cynoglossus macrolepidotus, Machrobrachium malcolmsonni found at downsteam locations. Mean values were $1.47 \mathrm{mg} / \mathrm{kg}$ in muscle 
and $1.67 \mathrm{mg} / \mathrm{kg}$ in intestine for fish species found at upstream locations and $1.3 \mathrm{mg} / \mathrm{kg}$ in muscle and $1.37 \mathrm{mg} / \mathrm{kg}$ in intestine for fish species found at downstream locations. The highest concentrations of lead were found to be $3.42 \mathrm{mg} / \mathrm{kg}$ and $2.96 \mathrm{mg} / \mathrm{kg}$ in Etroplus suratensis intestine and muscle respectively (upstream). The lowest lead concentrations were measured to be $0.67 \mathrm{mg} / \mathrm{kg}$ in muscle and $0.46 \mathrm{mg} / \mathrm{kg}$ in intestine in Liza Tade.

Table 5. Comparison of Heavy metal content of muscle, intestine ( $m g \mathrm{~kg}-1$ ) and water (mg lit-1) at downstream points

\begin{tabular}{|l|l||l|l|l||}
\hline \hline Sr. No. & Fish Organ & $\mathrm{Pb}$ & $\mathrm{Cd}$ & $\mathrm{Hg}$ \\
\hline \hline \multirow{2}{*}{5} & Intestine & $2.07 \pm 0.12 \mathrm{a}$ & $0.25 \pm 0.03 \mathrm{a}$ & $0.26 \pm 0.01 \mathrm{a}$ \\
\cline { 2 - 5 } & Muscle & $1.76 \pm 0.14 \mathrm{a}^{*} \mathrm{c}^{*}$ & $0.21 \pm 0.06 \mathrm{a}^{*}$ & $0.20 \pm 0.02 \mathrm{a} *$ \\
\hline 6 & Intestine & $0.83 \pm 0.09 \mathrm{bc}$ & $0.12 \pm 0.05 \mathrm{bd}$ & $0.08 \pm 0.01 \mathrm{bc}$ \\
\hline & Muscle & $0.97 \pm 0.07 \mathrm{~b} *$ & $0.08 \pm 0.01 \mathrm{~b}^{*}$ & $0.07 \pm 0.02 \mathrm{~b}^{*}$ \\
\hline 7 & Intestine & $1.18 \pm 0.15 \mathrm{~cd}$ & $0.35 \pm 0.05 \mathrm{c}$ & $0.11 \pm 0.02 \mathrm{c}$ \\
\hline & Muscle & $1.48 \pm 0.11 \mathrm{c}^{*} \mathrm{a}^{*}$ & $0.21 \pm 0.04 \mathrm{a}^{*}$ & $0.09 \pm 0.03 \mathrm{c}^{*} \mathrm{~b}^{*}$ \\
\hline 8 & Intestine & $1.38 \pm 0.04 \mathrm{~d}$ & $0.14 \pm 0.07 \mathrm{~d}$ & $0.15 \pm 0.01 \mathrm{~d}$ \\
\hline & Muscle & $0.99 \pm 0.03 \mathrm{~b}^{*} \mathrm{~d}^{*}$ & $0.12 \pm 0.01 \mathrm{~d}^{*} \mathrm{a}^{*}$ & $0.08 \pm 0.01 \mathrm{bc}$ \\
\hline Water & & $0.31 \pm 0.02 \mathrm{e}$ & $0.05 \pm 0.01 \mathrm{~b}^{*}$ & $0.001 \pm 0.001 \mathrm{e}$ \\
\hline Criteria & FSSAl & $2.5-5$ & 1.5 & 0.5 \\
\hline $\begin{array}{l}\text { Data are presented as means } \pm \text { SE of three determinations. Means followed by the } \\
\text { same letter within columns are not significantly different at 5\% level }\end{array}$ \\
\hline
\end{tabular}

The mean levels of cadmium in muscle and intestine in fish, found at upstream locations, were $0.17 \mathrm{mg} / \mathrm{kg}$ and $0.23 \mathrm{mg} / \mathrm{kg}$, respectively and $0.16 \mathrm{mg} / \mathrm{kg}$ and $0.22 \mathrm{mg} / \mathrm{kg}$ at downstream points, respectively. The concentrations of cadmium of maximum value were found to be 0.25 and $0.29 \mathrm{mg} / \mathrm{kg}$ in Etroplus suratensis (upstream) muscle and intestine respectively. Least cadmium concentrations were found $0.08 \mathrm{mg} / \mathrm{kg}$ and $0.12 \mathrm{mg} / \mathrm{kg}$ in Cynoglossus macrolepidotus (downstream) muscle and intestine respectively.

The concentrations of mercury, for the two tissues, were not very different, with a mean of $0.17 \mathrm{mg} / \mathrm{kg}$ in muscle and 0.18 $\mathrm{mg} / \mathrm{kg}$ in intestine respectively (upstream) and $0.14 \mathrm{mg} / \mathrm{kg}$ in intestine and $0.11 \mathrm{mg} / \mathrm{kg}$ in muscle at downstream sites. Here again, lowest and highest concentration were found in muscle and intestine tissue of Cynoglossus macrolepidotus $(0.07 \mathrm{mg} / \mathrm{kg} \mathrm{\&} 0.08 \mathrm{mg} /$ $\mathrm{kg})$ and Etroplus suratensis $(0.25 \mathrm{mg} / \mathrm{kg} \& 0.26 \mathrm{mg} / \mathrm{kg})$ respectively.

\section{Discussion}

According to Albaster and Lloyd (1982), the uptake and absorption of metals by the organs of fish depend on the chemical properties and the prevailing water chemistry of the water from which experimental fish were caught. In general, different tissues showed different capacities for accumulating heavy metals. Higher metal concentrations were found in the intestine, while the muscle tended to accumulate less metal. Among the fish species, Etroplus suratensis, shows the highest potential of accumulating all three heavy metals. Although fish intestines are seldom consumed, it might represent as good biomonitors of metals present in the surrounding environment.

Heavy metals, such as lead $(\mathrm{Pb})$, mercury $(\mathrm{Hg})$ and cadmium $(\mathrm{Cd})$ are dangerous for human health because of their accumulation properties (Tressou et al., 2004). Metals bioaccumulation through aquatic food webs to fish, humans and other piscivorous animals are of environmental and human health concern. Laws (1981) had noted that differences in concentration of metals in different parts of an organism could be attributed to the tendency of metals to bind to various molecular groups found within the cells of organisms as well as the degree of exposure to metal as influenced by its metabolic characteristics and position in the food chain. This can be the reason as to why higher metal content is found in intestine than muscle. Also, from results, it can be seen that accumulation of heavy metals is not dependent on size of the fish.

The fact that toxic metals are present at high concentrations in fish is of particular importance in relation to the WHO and FSSAI standards. Lead is usually found in low concentrations in natural waters because Pb containing minerals are less soluble in water (Ravichandran \& Jayaprakash, 2011). In contrast, the levels were higher in the case of the Savitri River, which crosses the WHO limit of $0.01 \mathrm{mg} /$ lit. Similarly, higher levels of contamination were found in the organs of fish species for Pb. As per FSSAI, maximum permissible dose for human consumption is 2.5 to $5 \mathrm{ppm} \mathrm{Pb}$ by weight. Fish tissues were slightly contaminated by $\mathrm{Pb}$, but 
overall fit for consumption. However, the level in river water was above standard norms at both upstream and downstream locations and requires treatment operations at CETP, Mahad, to be monitored frequently. Lead causes renal failure and liver damage in humans (Emmerson, 1973).

Cd values were found to be just lower than the acceptable limit proposed by the WHO and FSSAI. The FSSAI proposed threshold values of metal concentrations in fish of $1.5 \mathrm{ppm}$ by weight. Cadmium can be accumulated with metallothioneins and uptake of 3-330mg/day is toxic and 1.5-9 mg/day is lethal to humans (Bowen, 1979). Cadmium injures kidneys and cause symptoms of chronic toxicity, including impairment of kidney function, poor reproductive capacity, hypertension, tumours and hepatic dysfunction (Waalkes, 2000).

The Hg values were well below the FSSAI recommended value of $0.5 \mathrm{ppm}$ by weight. Also concentration of mercury in river water was lower than recommended levels by WHO. Mercury concentrations of $5 \mathrm{ppm}$ (wet weight) in fish muscle can be associated with emaciation, decrease in coordination, losing appetite, and mortality in fish (Eisler, 1987). Mercury is a known human toxicant and the primary source of mercury contamination in people is through eating fish. Mercury pollution in aquatic ecosystems has received great attention since the discovery of mercury as the cause of Minamata disease in Japan in the 1950s. Mercury poisoning during nervous system development may cause catastrophic consequences in infants causing widespread neural impairment (Harada, 1995).

Periodic monitoring of these and other heavy metals in both the fishes and river system to ensure continuous safety of people in the area is recommended. Safe disposal of domestic wastes and industrial effluents should be practiced and where possible recycled to avoid these metals and other contaminants from going into the environment. Further studies on the concentration of heavy metals in other fish tissues (brain, liver, kidney, and heart) are recommended. Although levels of heavy metals are not high, a potential danger may emerge in the future depending on the industrial wastewaters and domestic activities in this region.

\section{Conclusion}

This study was carried out to provide information on heavy metal concentrations of muscle and intestine tissue in fish from the Savitri River in the Raigad district. All results were well below the limits for fish recommended by the Indian Food Safety \& Standards regulation, 2011. According to our results, the examined fish were within the limits for human consumption. High levels of heavy metals were found in intestines while the lower levels in muscle of species except for $\mathrm{Pb}$ and $\mathrm{Hg}$ in Species 4 found upstream and level of $\mathrm{Pb}$ in Species 6 and 7 found downstream. Also higher levels of metal concentration were found in upstream points as compared to downstream points. The levels of heavy metals in water are low, except $\mathrm{Pb}$, as compared to the standard norms. In future certain improvisations in the treatment operations of the CETP Mahad may be required to bring down levels of Pb, before discharging effluent in river water.

\section{Acknowledgements}

The authors are pleased to acknowledge the financial support offered by the State Government of Maharashtra and the management of Bharati Vidyapeeth Institute of Environment, Education \& Research, Katraj (BVIEER) for their constant encouragement and infrastructure facilities for this research work.

\section{References}

1 Aboul-Ezz A, Ibrahim S and Mohamed F (2001) Heavy metals concentrations in different organs of some fish caught from the Mediterranean Sea. $2^{\text {nd }}$ Int. Conf. \& Exhibition for Life and Environment. Alexandria, Egypt, pp: 384-404.

2- Ademoroti, CMA (1996) Environmental Chemistry and Toxicology. Fodulex Press, Ibadan.

3- Allen P (1995) Chronic Accumulation of Cadmium in the Edible Tissues of Oreochromis aureus (Steindachner): Modification by Mercury and Lead. Arch. Environ. Contam. Toxicol. 29, 8-14.

4- Al Quraishi S, Abdel-Baki AS, Dkhil MA. (2011) Bioaccumulation of some heavy metals in tilapia fish relevant to their concentration in water and sediment of Wadi Hanifah, Saudi Arabia. Afr. J. Biotechnol. 10(13). 2541-2547.

5• Ayas Z, Guler E, Sedat VY, Murat O. (2007) Heavy metal accumulation in water, sediments and fishes of Nallihan Bird Paradise, Turkey. J. Envt. Biology. 28(3):545-549.

6• APHA (2005) Standard Methods for the Examination of Water and Waste-Water.21 ${ }^{\text {st }}$ Edn. Washington, D.C.

7• Begum A, Harikrishna S and Khan I (2009) Analysis of heavy metals in water, sediments, and fish samples of Madivala lakes of 
Bangalore, Karnataka. Int. J. Chemtech. Res. 1(2): 245-249.

8 Bowen HJM (1979) Environmental chemistry of the elements. London Acad. Press. pp: 269.

9• Daka ER, Ekeh CA and Moslen M (2008) Cadmium and Lead levels in some fish species from Azuabie creek in the Bonny Estuary, Nigeria. Afr.J. Biotech. 7, 63-64.

10- Deb SC and Santra SC (1997) Bioaccumulation of metals in fishes: An in-vivo experimental study of sewage fed ecosystem. The Environmentalist. 17, 27-32.

11 - Eisler R. (1987) Mercury hazards to fish, wildlife, and invertebrates: a synoptic review. US Fish and wildlife Service Report, 85(1.10), Washington, DC, USA.

12. Emmerson, BT (1973) Chronic lead nephropathy (editorial). Kidney Int., 4, 1. Faculty of agriculture.

13• Food Safety and Standards Authority of India (FSSAI), F.No. 2-15015/30/2010

14- Harada M (1995) Minamata disease: methyl-mercury poisoning in Japan caused by environmental pollution. Crit. Rev.Toxicol. $25,1$.

15- Karnataka State Pollution Control Board (2002) Water quality monitoring of rivers 2. pp: 11-18.

16• Laws EA (1981) Aquatic Pollution. John-Wiley and Sons, Inc. New York.

17. Lokhande RS and Kelkar N (1999) Studies on heavy metals in water of Vasai Creek, Maharashtra. Indian J. Environ. Protect. $19,664-668$.

18- Oguzie FA (2003) Heavy metals in fish, water and effluents of lower Ikpoba River Benin City. Pak. J. Sci. Ind. Res. 46, 156-160.

19. Olaifa FE, Olaifa AK, Adelaja AA and Owolabi AG (2004) Heavy metal contamination of Clarias gariepinus from a Lake and fish farm in Ibadan Nigeria. Afr. J. Biomed. Res.7, 145-148.

20• Ozdmar K (1999) Biostatistics with SPSS. Kaan Book Co. Eskisehir.

21. Ozturk M, Ozozen G, Minareci O, Minareci E. (2009) Determination of heavy metals in fish, water and sediments of Avsar Dam Lake, Turkey. Iran. J. Envt. Health Sci. Eng. 6(2), 73-80.

22- Ozuni E, Dhaskali L, Abeshi J, Zogaj M, Haziri I, Beqiraj D and Latifi F (2010) Heavy metals in fish for public consumption and consumer protection Natura Montenegrina. Podgorica. 9(3), 843-851.

23• Nwani CD, Nwachi DA, Okogwu OI, Ude EF and Odoh GE (2010) Heavy metals in fish species. J. Environ. Biol. 31(5), 595601.

24- Rashed MN (2001) Cadmium and lead levels in fish (Tilapia nilotica) tissues as biological indicator for lake water pollution. Envt. Monitoring \& Assessment. 68, 75-89.

25. Ravichandran K and Jayaprakash M (2011) Seasonal variation on physic-chemical parameters and trace metals in groundwater of an industrial area of north Chennai, India. Indian J. Sci.Technol. 4(6), 646-649.

26• Samanta S, Mitra K, Chandra K, Saha K, Bandopadhyay S and Ghosh A (2005) Heavy metals in water of the rivers Hooghly and Haldi at Haldia and their impact on fish. J. Envt. Biol. 26, 517-523.

27• Senthilkumaar P, Eswari S, Velmurugan K and Sarojini S (2012) Independent toxic effects of metallic compounds on Indian major carps. Indian J. Sci. Technol. 5(8), 3142-3149.

28- Tressou J, Crepet A, Bertall P, Feinberg MH, LeBlanc JC (2004) Probabilistic exposure assessment to food chemicals based on extreme value theory. Application to heavy metals from fish and sea products. Food Chem. Toxicol. 42, 1349.

29• Vaithiyanathan P, Ramanathan AL and Subramanian V (1993) Transport and Distribution of Heavy Metals in Cauvery River. Water, Air, and Soil Pollution. 71, 13-28.

30 Van Loon JC (1980) Analytical Atomic Spectroscopy. Selected Methods. Academic Press, New York, 337pp.

31 Vettori MV, Allnovi R, Belletti S, Goidoni M, Franchini I, Mutti A (2003) In vitro models for the evaluation of the neurotoxicity of methyl-mercury. Current state of knowledge. Med.lav. 94. 183.

32. Waalkes MP (2000) Cadmium carcinogenesis in review. J.Inorganic Biochem. 79, 241.

33• WHO (1994) Guidelines for drinking water quality recommendation. World Health Organization, Geneva. 